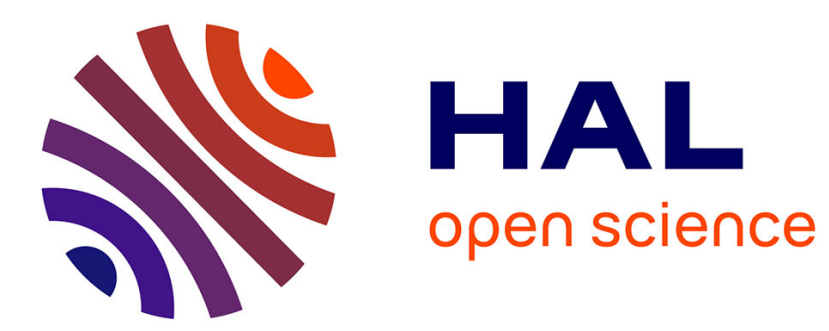

\title{
What have we learned form monogenic forms of severe insulin resistance associated with PCOS/HAIRAN?
}

\author{
Corinne Vigouroux
}

\section{To cite this version:}

Corinne Vigouroux. What have we learned form monogenic forms of severe insulin resistance associated with PCOS/HAIRAN?. Annales d'Endocrinologie, 2010, 71 (3), pp.222-4. 10.1016/j.ando.2010.02.017 . inserm-00848157

\section{HAL Id: inserm-00848157 https://www.hal.inserm.fr/inserm-00848157}

Submitted on 25 Jul 2013

HAL is a multi-disciplinary open access archive for the deposit and dissemination of scientific research documents, whether they are published or not. The documents may come from teaching and research institutions in France or abroad, or from public or private research centers.
L'archive ouverte pluridisciplinaire HAL, est destinée au dépôt et à la diffusion de documents scientifiques de niveau recherche, publiés ou non, émanant des établissements d'enseignement et de recherche français ou étrangers, des laboratoires publics ou privés. 


\section{What have we learned form monogenic forms of severe insulin resistance associated with PCOS/HAIRAN? \\ Qu'avons-nous appris des formes monogéniques d'insulino-résistance sévère associées au SOPK ?}

\section{Corinne Vigouroux}

Faculté de médecine Saint-Antoine, Université Paris 6 Pierre et Marie Curie, Centre de Recherches Saint-Antoine, INSERM UMR_S 938, 27, rue Chaligny, 75 571 Paris Cedex 12

Assistance-Publique-Hôpitaux de Paris, Service de Biochimie et Hormonologie, Hôpital Tenon, 4, rue de la Chine, 75970 Paris Cedex 20

tel 0140011484

fax 0140011432

corinne.vigouroux@inserm.fr

Insulin resistance and polycystic ovary syndrome (PCOS) have important but complex pathophysiological relationships. Both conditions are associated with type 2 diabetes and cardiovascular risks. However, obesity, which is an important contributor to these diseases, is a frequent confounding factor.

Severe insulin resistant states are observed in rare but very diverse diseases, of genetic or acquired origin, ranging from major dysfunctions of insulin receptor to abnormalities in lipid droplets formation and syndromes of body fat redistribution, in the absence of obesity. Hyperandrogenemia and PCOS are common findings in women with severe insulin resistance syndromes, whatever their causes.

Reports of the ovarian phenotypes in women with monogenic forms of severe insulin resistance syndromes have stimulated many studies about the roles of the ovarian insulin-insulin growth factor (IGF) system. In addition, PCOS features could be the referring signs leading to the diagnosis of several syndromes of severe insulin resistance.

\section{Primary dysfunctions of insulin receptors and PCOS}

The first clinical evidence for an important role of insulin in regulating ovarian functions came from the identification by $\mathrm{R}$. Kahn of severe insulin resistance syndromes with acanthosis nigricans and virilization in 1976 (1). The patients were 
described with hirsutism, polycystic ovaries, clitoral enlargement, and for some of them accelerated early growth and coarse figures (1). Therefore, it was proposed that insulin could enhance androgen production by the ovary. This hypothesis was reinforced later by the demonstration of insulin's ability to stimulate steroidogenesis in ovarian cells in vitro, and the identification of insulin receptors in stromal and follicular compartments of the human ovary (for review, see (2)). However, defects in the insulin signalling are located at the receptor level in these diseases, leading to insulin resistance and diabetes. Indeed, insulin receptor gene mutations or autoantibodies have then been shown to be responsible for type $A$ and type $B$ insulin resistance syndromes, respectively $(3,4)$. The ovary expressing not only insulin receptors, but also type I and type II IGF receptors (2), the most likely hypothesis is that the major hyperinsulinemia observed in type A insulin resistance syndromes acts on the ovary through the stimulation of IGF receptors. In addition, in severe insulin resistance syndrome, hyperinsulinemia is responsible for a decrease in the liver production of sex hormone binding globulin (SHBG) and IGF1 binding protein-1 (IGFBP-1), further enhancing the increase in free testosterone and IGF1 levels.

Concerning type B insulin resistance syndromes, auto-antibodies directed against insulin receptors could have complex effects, with inhibition and/or activation of the different insulin signalling pathways (5), that could differently modulate insulinmediated effects on the ovary.

\section{Lipodystrophic syndromes and PCOS}

Other syndromes of severe insulin resistance are associated with PCOS features. It is the case of lipodystrophic syndromes, either generalized, partial, genetic, or acquired (6). Recent studies have evidenced new molecular defects involved in these diseases (7-16), in favour of a primary role of adipose tissue development, and in particular of adipocyte lipid droplets formation, in generalized congenital lipoatrophies. Insulin resistance is thought to be secondary to the defective lipid storage in lipodystrophic adipose tissue, with post-receptor defects in insulinmediated signalisation events. In accordance, acromegaloid features (17) and liver steatosis (18) associated with severe insulin resistance syndromes have been explained by partial insulin resistance affecting glucose-lowering effects of insulin, but not insulin-activated mitogenic signals nor hepatic de novo lipogenesis, 
respectively. In accordance, a recent studies revealed an association between polymorphisms in two components of the insulin signalling pathways, AKT2 and GSK3 $\beta$, and PCOS (19). In addition, post-binding defects in insulin receptor signalling have been evidenced in common forms of PCOS $(20,21)$.

Whatever the origin of severe insulin resistance (primary insulin receptors defects or lipodystrophies), in vivo hyperinsulinemia has been clearly shown to promote ovarian growth and androgen synthesis independently of gonadotropins $(22,23)$.

\section{Endocrine defects of adipose tissue and PCOS}

In lipodystrophic syndromes, the endocrine deficiency of adipose tissue has been shown to play important pathophysiological roles in metabolic alterations. In particular, adiponectin and leptin are severely decreased, contributing to the ectopic lipid storage in non-adipose cells which inhibits insulin signalling (lipotoxicity). Leptin replacement therapy has been shown to restore menstrual functions in lipodystrophic women, which could be due to improvements in both insulin sensitivity and LH pulsatility $(24,25)$. However, the morphologic polycystic ovarian pattern did not change after leptin treatment. Conversely, the leptin replacement therapy of young hypoleptinemic children with congenital generalized lipoatrophic syndromes did not modify the onset of puberty (26). In addition, adiponectin deficiency probably does not play an important primary role in PCOS associated with severe insulin resistance syndromes. Indeed, adiponectin is decreased in lipodystrophies, but is significantly increased in patients with primary defects of insulin receptors (mutations or autoantibodies) as compared to controls, although the mechanisms are not known precisely $(27,28)$.

Finally, PCOS features are not always present in insulin resistance syndromes (2931). This is in favour of an aggravating, but not a primary role of insulin resistance on ovary dysfunctions.

Conversely, although the PCOS phenotype show a considerable heterogeneity in metabolic features, hirsutism and oligomenorrhea were shown to be the referring signs in several cases of severe insulin resistance syndromes $(32,33)$. 


\section{Conclusion}

Monogenic forms of severe insulin resistance associated with PCOS have highlighted the involvement of hyperinsulinemia in the ovarian pathophysiology. Although the pathogenic mechanisms are probably multifactorial, these diseases show the major contributor role for insulin resistance in ovarian dysfunction leading to PCOS. Conversely, at the clinical level, the careful characterization of patients with PCOS features can lead to diagnosis of rare severe insulin resistance syndromes, with and without lipodystrophy.

\section{References}

1. Kahn CR, Flier JS, Bar RS, Archer JA, Gorden P, Martin MM, et al. The syndromes of insulin resistance and acanthosis nigricans. Insulin-receptor disorders in man. N Engl J Med 1976;294:739-45

2. Poretsky L, Cataldo NA, Rosenwaks Z, Giudice LC. The insulin-related ovarian regulatory system in health and disease. Endocr Rev 1999;20:535-82

3. Flier JS, Kahn CR, Roth J, Bar RS. Antibodies that impair insulin receptor binding in an unusual diabetic syndrome with severe insulin resistance. Science 1975;190:63-5

4. Moller DE, Flier JS. Detection of an alteration in the insulin-receptor gene in a patient with insulin resistance, acanthosis nigricans, and the polycystic ovary syndrome (type A insulin resistance). N Engl J Med 1988;319:1526-9

5. Auclair M, Vigouroux C, Desbois-Mouthon C, Deibener J, Kaminski P, Lascols $\mathrm{O}$, et al. Antiinsulin receptor autoantibodies induce insulin receptors to constitutively associate with insulin receptor substrate-1 and -2 and cause severe cell resistance to both insulin and insulin-like growth factor I. J Clin Endocrinol Metab 1999;84:3197-206

6. Garg A. Acquired and inherited lipodystrophies. N Engl J Med 2004;350:122034

7. Magré J, Delepine M, Khallouf E, Gedde-Dahl T, Jr., Van Maldergem L, Sobel $E$, et al. Identification of the gene altered in Berardinelli-Seip congenital lipodystrophy on chromosome 11q13. Nat Genet 2001;28:365-70

8. Agarwal AK, Arioglu E, De Almeida S, Akkoc N, Taylor SI, Bowcock AM, et al. AGPAT2 is mutated in congenital generalized lipodystrophy linked to chromosome 9q34. Nat Genet 2002;31:21-3

9. Szymanski KM, Binns D, Bartz R, Grishin NV, Li WP, Agarwal AK, et al. The lipodystrophy protein seipin is found at endoplasmic reticulum lipid droplet junctions and is important for droplet morphology. Proc Natl Acad Sci U S A 2007;104:20890-5

10. Fei W, Shui G, Gaeta B, Du X, Kuerschner L, Li P, et al. Fld1p, a functional homologue of human seipin, regulates the size of lipid droplets in yeast. J Cell Biol 2008; 180:473-82 
11. Payne VA, Grimsey N, Tuthill A, Virtue S, Gray SL, Dalla Nora E, et al. The human lipodystrophy gene BSCL2/seipin may be essential for normal adipocyte differentiation. Diabetes 2008;57:2055-60

12. Chen W, Yechoor VK, Chang BH, Li MV, March KL, Chan L The human lipodystrophy gene product Berardinelli-Seip congenital lipodystrophy 2/seipin plays a key role in adipocyte differentiation. Endocrinology 2009;150:4552-61

13. Kim CA, Delepine M, Boutet E, El Mourabit H, Le Lay S, Meier M, et al. Association of a homozygous nonsense caveolin-1 mutation with BerardinelliSeip congenital lipodystrophy. J Clin Endocrinol Metab 2008;93:1129-34

14. Boutet E, El Mourabit H, Prot M, Nemani M, Khallouf E, Colard O, et al. Seipin deficiency alters fatty acid Delta9 desaturation and lipid droplet formation in Berardinelli-Seip congenital lipodystrophy. Biochimie 2009;91:796-803

15. Rubio-Cabezas O, Puri V, I. M, Saudek V, Semple RK, Dash S, et al. Partial lipodystrophy and insulin resistant diabetes in a patient with a homozygous nonsense mutation in CIDEC. EMBO Mol Med 2009;1:280-87

16. Hayashi YK, Matsuda C, Ogawa M, Goto K, Tominaga K, Mitsuhashi S, et al. Human PTRF mutations cause secondary deficiency of caveolins resulting in muscular dystrophy with generalized lipodystrophy. $J$ Clin Invest 2009;119:2623-33

17. Flier JS, Moller DE, Moses AC, O'Rahilly S, Chaiken RL, Grigorescu F, et al. Insulin-mediated pseudoacromegaly: clinical and biochemical characterization of a syndrome of selective insulin resistance. J Clin Endocrinol Metab 1993;76:1533-41

18. Semple RK, Sleigh A, Murgatroyd PR, Adams CA, Bluck L, Jackson S, et al. Postreceptor insulin resistance contributes to human dyslipidemia and hepatic steatosis. J Clin Invest 2009;119:315-22

19. Goodarzi MO, Jones MR, Chen YD, Azziz R. First evidence of genetic association between AKT2 and polycystic ovary syndrome. Diabetes Care 2008;31:2284-7

20. Dunaif A. Insulin resistance in women with polycystic ovary syndrome. Fertil Steril 2006;86 Suppl 1:S13-4

21. Diamanti-Kandarakis E, Papavassiliou AG. Molecular mechanisms of insulin resistance in polycystic ovary syndrome. Trends Mol Med 2006;12:324-32

22. Musso C, Shawker T, Cochran E, Javor ED, Young J, Gorden P. Clinical evidence that hyperinsulinaemia independent of gonadotropins stimulates ovarian growth. Clin Endocrinol (Oxf) 2005;63:73-8

23. Vambergue A, Lautier C, Valat AS, Cortet-Rudelli C, Grigorescu F, Dewailly D. Follow-up study of two sisters with type A syndrome of severe insulin resistance gives a new insight into PCOS pathogenesis in relation to puberty and pregnancy outcome: a case report. Hum Reprod 2006;21:1274-8

24. Oral EA, Ruiz E, Andewelt A, Sebring N, Wagner AJ, Depaoli AM, et al. Effect of leptin replacement on pituitary hormone regulation in patients with severe lipodystrophy. J Clin Endocrinol Metab 2002;87:3110-7

25. Musso C, Cochran E, Javor E, Young J, Depaoli AM, Gorden P. The long-term effect of recombinant methionyl human leptin therapy on hyperandrogenism and menstrual function in female and pituitary function in male and female hypoleptinemic lipodystrophic patients. Metabolism 2005;54:255-63

26. Beltrand J, Beregszaszi M, Chevenne D, Sebag G, De Kerdanet M, Huet F, et al. Metabolic correction induced by leptin replacement treatment in young 
children with Berardinelli-Seip congenital lipoatrophy. Pediatrics 2007;120:e291-6

27. Semple RK, Soos MA, Luan J, Mitchell CS, Wilson JC, Gurnell M, et al. Elevated plasma adiponectin in humans with genetically defective insulin receptors. J Clin Endocrinol Metab 2006;91:3219-23

28. Semple RK, Cochran EK, Soos MA, Burling KA, Savage DB, Gorden P, et al. Plasma adiponectin as a marker of insulin receptor dysfunction: clinical utility in severe insulin resistance. Diabetes Care 2008;31:977-9

29. Andreelli F, Hanaire-Broutin H, Laville M, Tauber JP, Riou JP, Thivolet C. Normal reproductive function in leptin-deficient patients with lipoatropic diabetes. J Clin Endocrinol Metab 2000;85:715-9

30. Johnsen S, Dolan SE, Fitch KV, Killilea KM, Shifren JL, Grinspoon SK. Absence of polycystic ovary syndrome features in human immunodeficiency virus-infected women despite significant hyperinsulinemia and truncal adiposity. J Clin Endocrinol Metab 2005;90:5596-604

31. Decaudain A, Vantyghem MC, Guerci B, Hecart AC, Auclair M, Reznik Y, et al. New metabolic phenotypes in laminopathies: LMNA mutations in patients with severe metabolic syndrome. J Clin Endocrinol Metab 2007;92:4835-44

32. Keller J, Subramanyam L, Simha V, Gustofson R, Minjarez D, Garg A. Lipodystrophy: an unusual diagnosis in a case of oligomenorrhea and hirsutism. Obstet Gynecol 2009;114:427-31

33. Young J, Morbois-Trabut L, Couzinet $B$, Lascols $\mathrm{O}$, Dion E, Béréziat $\mathrm{V}$, et al. Type A insulin resistance syndrome revealing a novel lamin A mutation. Diabetes 2005;54:1873-8 